\title{
Effect of Smoking on Blood Sugar and Serum Lipids in Smoker and Non- smoker Stroke Patient
}

\author{
Nasrin Habib ${ }^{1}$, U.S. Naima Begum ${ }^{2}$, Najneen Akhter ${ }^{3}$, Dilruba Akther ${ }^{4}$, Mamunur Rashid ${ }^{5}$
}

\begin{abstract}
:
This descriptive study was carried out in the Department of Physiology, Dhaka Medical College, Dhaka, during the period of Jamuary 2008 to December 2008. The objective of the study was to measure blood sugar and serum lipid profile in smoker and nonsmoker stroke patients and to find out changes of blood sugar and serum lipids among them. To accomplish the purpose, 105 adult male stroke patient of over 20 years of age were selected. They were divided into no groups: Group A consisting of 30 non-smokers and group B consisting of 75 smoker stroke patients. It was found that smoking caused no significant differences ( $p>0.05)$ in blood sugar level and significant differences $(p<0.05)$ in serum lipids between smokers and non -smokers. This study provides the scope to understand whether there was altered physiology in smoker stroke patients.
\end{abstract}

\section{Introduction:}

Stroke is a leading cause of death and disability, and has an enormous physical, emotional and economic impact on patients, families and society.' It is the major cause of hospitalization, prolong disability and mortality in many populations. Stroke imposes an enormous burden on the healthcare resources and economic well being of the affected persons and their respective families.

1. Assistant Professor of Physiology, Holy Family Red Crescent Medical College, Dhaka.

2. Professor of Physiology, Holy Family Red Crescent Medical College, Dhaka.

3. Associate Professor of Physiology, Holy Family Red Crescent Medical College, Dhaka.

4. Assistant Professor of Physiology, Holy Family Red Crescent Medical College, Dhaka.

5. Assistant Registrar of Internal Medicine, Dhaka Medical College and Hospital, Dhaka.
It is calculated that stroke is going to be the fifth leading cause of disease burden in developing countries by $2020^{2}$. Diabetes can damage entire circulatory system and is a risk factor for stroke. Those with high blood sugar (glucose) when they are admitted to the hospital are at a higher risk of dying within 30 days, one year, or five years after their stroke. They also have longer hospital stays and cause higher hospital costs than patients with normal blood sugar level ${ }^{3}$.

A number of studies have examined the association between smoking and incidence of glucose abnormalities, and have suggested that smoking could bc independently associated with glucose intolerance, impaired fasting glucose and type 2 diabetes, which could make smoking a modifiable risk factor for type 2 diabetes. Analysis of the data indicated that active smokers have a $44 \%$ 
increased risk of developing type 2 diabetes compared to non-smokers ${ }^{4}$.

In diabetes, biochemical abnormalities may cause reduced entry of glucose into various peripheral tissues and increased liberation of glucose into the circulation from the liver. Therefore, there is an extracellular glucose excess and in many cells intracellular glucose deficiency. So, impaired glucose tolerance in diabetes is due to decreased peripheral utilization. The activity of the hormonesensitive lipase is increased by fasting and stress. The intracellular hormone-sensitive lipase of adipose tissue catalyzes the breakdown of triglycerides into glycerol and fatty acids, with the latter entering the circulation. They are synthesized in the fat depots in which they are stored. They are used extensively in the heart, but probably in all tissues, including the brain'.

Smoking cigarettes has an important effect on plasma lipoprotein metabolism through multiple mechanisms ${ }^{5}$. Smoking stimulates oxidation of LDL particles, producing a significant increase of triglycerides and a decrease of HDL-cholesterol, mostly due to HDL subfraction diminution ${ }^{6}$. Smokers have significantly higher serum concentrations of cholesterol $(3.0 \%)$, triglycerides $(9.1 \%)$, very low density lipoprotein cholesterol $(10.4 \%)$, and low density lipoprotein cholesterol $(1.7 \%)$, and lower serum concentrations of high density lipoprotein cholesterol $(-5.7 \%)$ and apolipoprotein $\mathrm{AI}(-4.2 \%)$ compared with nonsmokers. Increased serum cholesterol concentration in smokers may account for at least $9 \%$ of excess risk. Furthermore, the dose response effect of smoking on serum cholesterol concentration suggests a gradient of increased absolute risk of coronary artery disease between light and heavy smokers ${ }^{7}$.
So, the present study was done to find out the changes of blood sugar and serum lipids among the smoker and non-smoker stroke patients.

\section{Materials and method:}

The study was done to compare the blood sugar and serum lipid levels in adult male smokers and non-smoker stroke patients. For this purpose, 105 subjects age over 20 years were selected, of whom, 30 were non-smokers and 75 were smokers who smoked for more than five years. The participants were selected from indoor medicine units of Dhaka Medical College Hospital. Smoking history of smokers was recorded on a data collection sheet. All the subjects were explained about the aims and objectives of the study. The test procedures were briefed. Written consent was taken from the person concerned in a prescribed form. A detailed history of each subject including smoking history was obtained by using a pre-tested questionnaire. Sample for random blood sugar and serum lipids were sent to the clinical laboratory of Dhaka Medical College Hospital. All data were recorded in data collection form. Statistical analysis of results between the groups was calculated by using unpaired students ' $t$ ' test.

\section{Results:}

In this study, the mean $( \pm$ SD) age of the nonsmoker subjects were $61.70 \pm 16.379$. Among them, five $(16.7 \%)$ had history of diabetes mellitus (DM), 15 (50\%) had first admission due to stroke and nine (30\%) had family history of stroke. DM was found controlled in one $(3.3 \%)$, uncontrolled in two $(6.7 \%)$ and status not known in twenty seven patients $(90 \%)$. Among the smoker subjects, the mean 
Table-I: History of diabetes mellitus, first admission due to stroke and family history of stroke

\begin{tabular}{|l|c|c|c|c|c|c|c|}
\hline \multirow{2}{*}{ Group } & \multirow{2}{*}{ Number } & \multicolumn{2}{|c|}{$\begin{array}{c}\text { History of diabetes } \\
\text { mellitus }\end{array}$} & \multicolumn{2}{c|}{$\begin{array}{c}\text { First admission due to } \\
\text { stroke }\end{array}$} & \multicolumn{2}{c|}{$\begin{array}{c}\text { Family history of } \\
\text { stroke }\end{array}$} \\
\cline { 3 - 8 } & & Yes & No & Yes & No & Yes & No \\
\hline Group A & 30 & $\begin{array}{c}05 \\
(16.7 \%)\end{array}$ & $\begin{array}{c}25 \\
(83.3 \%)\end{array}$ & $\begin{array}{c}15 \\
(50.0 \%)\end{array}$ & $\begin{array}{c}15 \\
(50.0 \%)\end{array}$ & $\begin{array}{c}09 \\
(30.0 \%)\end{array}$ & $\begin{array}{c}21 \\
(70.0 \%)\end{array}$ \\
\hline Group B & 75 & $\begin{array}{c}09 \\
(12.0 \%)\end{array}$ & $\begin{array}{c}66 \\
(88.0 \%)\end{array}$ & $\begin{array}{c}52 \\
(69.3 \%)\end{array}$ & $\begin{array}{c}23 \\
(30.7 \%)\end{array}$ & $\begin{array}{c}20 \\
(26.7 \%)\end{array}$ & $\begin{array}{c}55 \\
(73.3 \%)\end{array}$ \\
\hline
\end{tabular}

Table-II: Status of diabetes mellitus

\begin{tabular}{|l|c|c|c|}
\hline Group & Controlled & Uncontrolled & Not known \\
\hline Group A & $01(3.3 \%)$ & $02(6.7 \%)$ & $27(90.0 \%)$ \\
\hline Group B & $05(6.7 \%)$ & $03(4.0 \%)$ & $67(89.3 \%)$ \\
\hline
\end{tabular}

$( \pm S D)$ age was $62.61 \pm 15.803$ years. Of them, nine $(12.0 \%)$ had history of DM, $52(69.3 \%)$ had first admission due to stroke and 20 $(26.7 \%)$ had family history of stroke. DM was found controlled in five $(6.7 \%)$, uncontrolled in three $(4 \%)$, status not known in $67(89.3 \%)$. The findings are shown in Tables -I and II.

The mean $( \pm \mathrm{SD})$ of measured values of blood sugar were $7.1137 \pm 3.69111 \mathrm{mmol} / \mathrm{L}$ in Group $\mathrm{A}$ and $6.7565 \pm 2.40351 \mathrm{mmol} / \mathrm{L}$ Group B. There were no significant $(p>0.05)$ differences in blood sugar level between Group $A$ and Group B.

The mean $( \pm \mathrm{SD})$ of measured values of serum total cholesterol were $5.201 \pm 0.523 \mathrm{mmol} / \mathrm{L}$ in Group $\mathrm{A}$ and $7.21 \pm 1.432 \mathrm{mmol} / \mathrm{L}$ Group B. There was significant $(\mathrm{p}<0.02)$ difference in serum total cholesterol between Group A and Group B.

The mean $( \pm S D)$ of measured values of triglyceride were $0.621 \pm 0.113 \mathrm{mmol} / \mathrm{L}$ in Group A and $3.7532 \pm 1.351$ Group B. There was significant $(p<0.002)$ difference in triglyceride between Group A and Group B.

The mean $( \pm S D)$ of measured values of $L D L$ C level were $2.4137 \pm 0.311 \mathrm{mmol} / \mathrm{L}$ in Group $A$ and $4.065 \pm 0.1351 \mathrm{mmol} / \mathrm{L}$ Group B respectively. The difference was significant $(\mathrm{p}<0.001)$

The mean $( \pm S D)$ of measured values of HDL$\mathrm{C}$ level were $0.9713 \pm 0.118 \mathrm{mmol} / \mathrm{L}$ in Group $A$ and $0.7065 \pm 0.0351 \mathrm{mmol} / \mathrm{L}$ Group $B$ respectively. The difference was also significant $(p<0.002)$.

\section{Discussion:}

Diabetes can damage entire circulatory system. When blood glucose level rises, lactic acid begins to build up in various tissues, including the brain. When there is insufficient blood flow, as in stroke, this acid build-up accelerates a series of reactions that cause cell death following a stroke. Diabetes can make a person two to three times more prone to stroke ${ }^{3}$. 


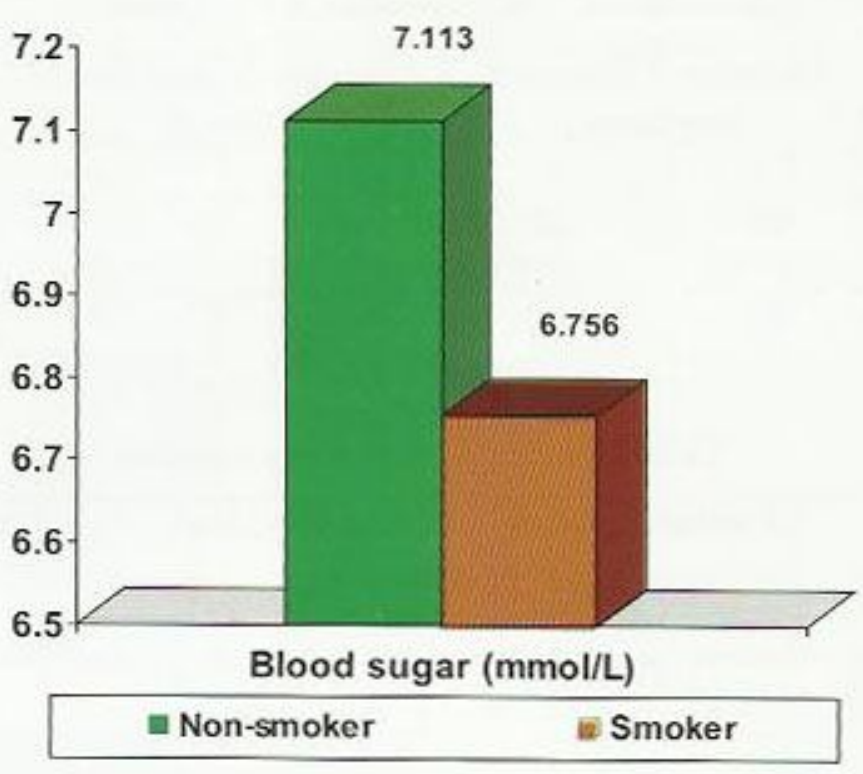

Figure 1: Mean of calculated values of blood sugar in different groups of subjects.

In one of the previous studies, smokers were found to have significantly higher fasting glucose $(5.8+/-0.6 \mathrm{mmol} / \mathrm{l})$ than non-smokers (fasting glucose: $5.1+/-0.7 \mathrm{mmol} / 1, \mathrm{p}<$ $0.010)^{8}$. In several other studies, smokers were found to have significantly higher blood sugar than non-smokers. It may be due to higher rates of metabolic syndrome among the smokers $^{9.13}$.

In this study, out of 30 non-smoker $16.7 \%$ had history of DM and $30 \%$ had family history of stroke and their DM were uncontrolled in $6.7 \%$. Among the smoker subjects, out of 75 patients, only $12 \%$ subjects had history of DM and $27 \%$ had family history of stroke and their DM were uncontrolled in $4 \%$. According to the observation, the mean $( \pm S D)$ of measured values of blood sugar were $7.1137 \pm 3.69111$ in Group A (non-smokers) and 6.7565 \pm 2.40351 in group B (smokers). There were no significant $(\mathrm{p}>0.05)$ differences of blood sugar in Group A than Group B. Also in a crosssectional study, smoking was not found associated with insulin resistance as assessed by a modified glucose tolerance test ${ }^{14}$.

Results showed that smokers had significantly higher serum total cholesterol ( $\mathrm{P}=0.02)$, triglyceride $(\mathrm{P}=0.002)$ and LDL-C level $(P=0.001)$ and significantly lower HDL-C level $(\mathrm{P}=0.002)$ compared to nonsmokers. Other studies have showed that smoking causes decrease of HDL-cholesterol (HDL-C) levels and increase of total cholesterol, triglyceride and LDL-cholesterol (LDL-C) levels, ${ }^{5,15}$. Here the number of study population subject was small; therefore, the result may become different if the size of sample is increased.

\section{References:}

1. Ganong WE. In: Review of Medical Physiology, Twentieth edition. New York: Me Graw Hill, 2001. pp- 223-59, 340, 305.

2. Neurological, psychiatric and development disorder: meeting the challenge in the developing world. National Academic Press, 2001. pp- 82-5. 
3. Williams LS, Rotich J, Qi R, Fineberg N, Espay A, Bruno A, et al. Effects of admission hyperglycemia on mortality and costs in acute ischemic stroke. Neurology 2002: $59: 67-7$.

4. Science Daily. Smoking Associated With Increased Risk Of Diabetes, Study Finds. [Online]. [Cited 2007 Dec 12]; Available from:

URL.http://www.sciencedaily.com/release $\underline{s / 2007 / 12 / 07121123404 .}$

5. Freeman DJ, Griffin BA, Murray E, et al. Smoking and plasma lipoproteins in man: effects on low density lipoprotein cholesterol levels and high density lipoprotein subfraction distribution. Eur $\mathrm{J}$ Clin Invest 1993; 23: 630-40.

6. Lepsanović L, Brkljac O, Lepsanović L. Effect of smoking on lipoprotein metabolism. Med Pregl 2001; 54: 453-8.

7. Craig WY, Palomaki GE, Haddow JE. Cigarette smoking and scrum lipid and lipoprotein concentrations: an analysis of published data. BMJ 1989; 298: 784-788.

8. Dzien A, Dzien-Bischinger C, Hoppichler $\mathrm{F}$, Lechleitner M. The metabolic syndrome as a link between smoking and cardiovascular disease. Diabetes Obes Metab 2004; 6: 127-32.
9. Geslain-Biquez C, Vol S, Tichet J, et al. Study Group. The metabolic syndrome in smokers. The DESIR study. Diabetes Mctab 2003; 29: 226-34.

10. Facchini FS, Hollenbeck CB, Jeppesen J, et al. Insulin resistance and cigarette smoking. Lancet 1992; 339: 1128-30.

11. Eliasson B. Cigarette smoking and diabetes. Prog Cardiovasc Dis 2003; 45: 405-13.

12. Willi C, Bodenmann P, Ghali WA, Faris $\mathrm{PD}$, Cormuz J. Active smoking and the risk of type 2 diabetes: a systematic review and meta-analysis. JAMA 2007; 298: 265464.

13. Manson JE, Ajani UA, Liu S, Nathan DM, Hennekens $\mathrm{CH}$. A prospective study of cigarette smoking and the incidence of diabetes mellitus among US male physicians. Am J Med 2000; 109: 538-42.

14. Henkin L, Zaccaro D, Haffner S, et al. Cigarette smoking, environmental tobacco smoke exposure and insulin sensitivity: the Insulin Resistance Atherosclerosis Study. Ann Epidemiol 1999; 9: 290-6.

15. Batic-Mujanovic O, Beganlic A, Salihefendic N, Pranjic N, Kusljugic Z. Influence of smoking on serum lipid and lipoprotein levels among family medicine patients. Med Arch 2008; 62: 264-7. 